\title{
Marketing Education In A Changing Educational Environment
}

\author{
Robert L. Johnson, University of Phoenix
}

\begin{abstract}
Traditional academe as well as the new for-profit upstarts have suddenly gotten aggressively involved in marketing education. This paper will look at post secondary higher educational institutions, their marketing activities and the changes technology has triggered in curriculum, the rise of innovative marketing activities in both traditional and distance education, the role for-profit institutions has had on marketing methods, and what does it all mean for administrators in an age of changing values on what an education should be as well as cope with the increasing demand for expanded enrollment in order to survive.
\end{abstract}

\section{INTRODUCTION}

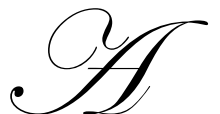

tidal wave of change is happening on one of America's biggest and most revered institutions, education. Traditional academe as well as the new for-profit upstarts have suddenly gotten aggressively involved in marketing education. This is being brought about by "a ... dramatic series of changes caused by private enterprise moving into the field" (Buchen, 1999, p. 38). The financial and institutional impact of this revolution is astounding. Education is a $\$ 700$ billion a year industry with half of that spent on higher education. Additionally, the for-profit educational institutions are coming into power through aggressive marketing. Students as consumers are presented with plenty of options to meet their education needs. "Adults are going back to school in droves, many by the demands of a market place that has little patience for academic or technological laggards" (Greenberg, 2000, p. 14).

This paper will look at post secondary higher educational institutions, their marketing activities and the changes technology has triggered in curriculum, the rise of innovative marketing activities in both traditional and distance education, the role for-profit institutions has had on marketing methods, and what does it all mean for administrators in an age of changing values on what an education should be as well as cope with the increasing demand for expanded enrollment in order to survive. As crass or un-academic as it may sound, education has got to learn to sell itself.

\section{WHY HAS AGGRESSIVE MARKETING BECOME AN ISSUE HIGHER EDUCATION}

Who are these new breed of entrepreneurial educational institutions causing this change? "It's the accredited, degree-granting, for-profit institutions like the University of Phoenix . . D DeVry . . ITT, Education Management, and Strayre Education, Inc." (Winston, 1999, p. 12). Wall Street is paying close attention to these organizations also. "These are the glamour stocks on NASDAQ . . [and] these institutions are getting lots of attention - clearly fed by the nation's disenchantment with traditional colleges and universities and its infatuation with 'privatizing' and 'the market"' (Winston, 1999, p. 12). Is this good for the system? Many educators, business professional, and even the students, have debated adamantly both ways, however, "these schools, it is suggested, will harness the limitless powers of free enterprise to mend a failed higher education institution stuck in the past". (Winston, 1999, p. 12). The for-profits are practicing what they teach in their business schools and bring in the students and the revenues that are not going to the non-profits and state run schools. What is going on? "An article in MacLeans's magazine states that because of reduced public funding, universities are 'scanning the marketplace, listening closely to their customers [students], and mercilessly reassessing the products they produce"” (Driscoll \& Wicks, 1998, p. 58). Notice, the universities are referring to students as customers. The for-profit educational 
institutions are coming into power through aggressive marketing. Additionally, "knowledge is power, and it's becoming increasingly accessible. That's because the expanding curriculum available on the Web has put the tools for obtaining a well rounded education literally at the fingertips of anyone with Internet access" (Thomas, 1999, p. $331)$.

\section{WHY CHANGE NOW}

In a system that is not always looked on favorably by the public, what alternatives do state run or private educational institutions have but to change? There appears to be two options. One would be "the nonprofit school[s] might fight back, making significant changes in what it does and how it does business, ....the other alternative . . . is that the weakened nonprofit school[s] might well sell out to a for profit firm" (Winston, 1999). One must consider that state run and non-profit higher education organizations never seem to have enough money no matter how much it given them by state legislatures, endowments, fund raisings, or collected by increased tuition. Do the for-profits have the key?

Analyst compare education today to the health care industry twenty years ago. Until the 1970s, health care was inefficiently managed and dominated by the public sector and non profit entities that had little direct competition and little incentive for innovation. Costs rose markedly without corresponding improvement in the quality of care (Garber, 1996, p. 57).

Today, educators and their administrators need to be concerned about cost, competition, service quality, and think of students as, God forbid, customers. How does the public feel about it? "The market-minded, who often deride universities as flabby places filled with slackers and ideologues, have enthusiastically welcomed the arrival of the for-profit universities" (Kirp, 2003). The stampede of investment professionals who see the market for-profit education is gaining momentum. Education truly has a unique opportunity in history to become competitive, innovative, earn profits, join a technologically changing world, and improve quality. Competition in the marketing arena has only helped the consumer. The same is true of competition in education. The consumer, the student, will be better served.

\section{HOW HAS TECHNOLOGY AND DISTANCE EDUCATION IMPACTED THE ENROLLMENT STRATEGIES OF TRADITIONAL INSTITUTIONS}

Online distance education is on the increase, especially by the for-profits. Why would a traditional educational institution want to start competing for distance education on the internet? "The market for distance education enrollments in higher education is expected to grow from 710,000 to 2.3 million" (Heller \& Associates, 2000 , p. 9). The rapid increase in for-profit enrollment, and financially impoverished state budgets in a troubled economy is placing a strain on cash strapped private and state supported schools. Universities need to earn revenues or profits to meet expenses, build new facilities, pay faculty a competitive wage, develop curriculum, and conduct research. One state university decided to get on the band wagon. Starting an online program, "over the last five academic years, University Maryland University College (UMUC) online enrollments have doubled or tripled in each succeeding year. During the last academic year, the university had more than 21,000 online enrollments" (Heller \& Associates, 2000, p. 9). According to the Heller Report, the revenues generated by the increased enrollments has allowed the university to "to better serve its ... students, with the goal of enhancing services and holding - or even reducing costs to students ... (Heller \& Associates, 2000, p. 9).

Even officials at Harvard "are considering moves to capitalize on its name and reputation in cyberspace" by venturing into and marketing the online education modality to enhance its revenues (Cox \& Associates, 1999, p. 53). Why would a prestigious educational institution like Harvard want to go online?

The entry of Harvard and other "elite" colleges into the degree-granting distance learning business may not be so much a sign of distance learning's abrupt ascendancy to "credibility," but rather, an institutional branding strategy that will help Harvard maintain its competitive advantage among its peers (DiSalvio, 2003, p. 72). 
From a marketing perspective, this decision by Harvard raises many eyebrows and triggers many philosophical and strategic questions. "Should the university dilute itself - its brand name recognition" (Cox \& Associates, 1999, p. 53). Harvey Fineberg, the University provost answers the question with some marketing questions of his own. He asks, "does quality and exclusivity equate one to the other?.....It's arguable. Exclusivity is the wrong dimension of expression of quality of the Harvard experience. If you read an excellent book, does it matter that there are 100 or 100,000 copies" (Cox \& Associates, 1999, p. 53)?

No one will argue that running an educational institution is expensive. University administrators are always asking for more funds from the legislature or conducting fund raisers in order to meet their financial needs. When one of the more cash rich universities was asked about its fund raising activities, the University of Phoenix "founder John Sperling replied, 'We don't need an endowment. We have Wall Street' (Garber, 1996, p. 58). While it may sound arrogant to staid academe and money indeed may not be everything, however, when one has it, it allows for an ability to concentrate on providing better quality education, develop new degree programs, purchase a new technology lab, or increase faculty pay. As they teach in finance, cash is king.

\section{WHAT ARE THE DRAWBACKS OF FOR-PROFIT EDUCATION}

Does for-profit education make sense, or is there good in for-profit education? The potential for new educational services and products is as limitless as the creativity of the human mind and the dynamism of a competitive marketplace. Michael Heise, law professor and director of Indiana University's Center of Education Law and Policy, puts it this way: 'Investors are chiseling away at the dam of the lasts remaining government monopoly in the world. Were the dam to break, I expect there would be a flood of investment in educational research and development" (Garber, 1996, p. 58). This flood of investment cannot but benefit the cash starved educational institutions. They could afford to pay the top salaries to attract the top expertise in their field, offer improved student services, and keep tuition fair. Competition does this.

The question to be asked and answered from a marketing perspective, who is using the for-profit schools as well as the online or distance modality for education? Sharon Thomas answers this by noting "Web based courses are particularly effective for older students, who are often more highly motivated. Others who find particular benefit in digital schooling include those who live overseas or in remote areas, as well as in prisons or hospitals" (Thomas, 1999, p. 331). This allows an educational institution to market beyond its borders. Technology is changing the jargon in the campus enrollment offices. "The talk at top campuses these days is about 'bytes of delivery' and 'branding."' (Marcus, 2000. p. 45). This presents new challenges to marketing professionals as well as unlimited opportunities to those willing to embrace the strategies early in the game. Waiting to see what happens before acting is the wrong marketing policy for today's academic institutions to follow. Business schools had better start acting like a business. After all, you can't lead where you don't go.

\section{HOW HAS THE ACADEMIC COMMUNITY REACTED TO ONLINE EDUCATION}

This has created turf wars among states for students. "Neil George, Vice President of Webster, plans to send courses directly to students anywhere in the world as Internet speeds improves. 'A state cannot stop one of its citizens from taking a course in his living room,' George says" (Marcus, 2000. p. 45). This raises all kinds of marketing issues never before studied or researched. The techniques of e-marketing, e-commerce, and e-education are rapidly becoming specialties unto themselves. What a wealth of opportunities for marketing researchers to explore and university marketing (enrollment) departments to take advantage of. The question now becomes how are universities fairing with these new ventures and what are they doing to deal with it?

Columbia University hired an executive from NFL.com to start a for profit spinoff that will market courses on the Internet. Meanwhile, Columbia's Teachers College has hits on nonprofit arm, TC Ventures, and Columbia Business School has joined UNext.com, a new company backed by financier Michael Milken that will sell online courses to corporate employees (Marcus, 2000. p. 45). 
These entrepreneurial ventures are going all out to apply sound business principles to develop quality, brand recognition, sophisticated marketing techniques, and quality to sell for-profit higher education. "UNext.com has signed up Stanford University, the University of Chicago, and the London School of Economics and Political Science to provide course materials and lecture videos from leading instructors" (Marcus, 2000. p. 45). These are some big names in education. These schools will test the marketing waters and improve on what seems to work.

There has been once success in marketing for-profit post secondary education and that is the University of Phoenix. They are a for-profit company under the Apollo Group Holding Group and are traded on the NASDAQ with the symbol APOL. They spun off the online portion of their company calling it University of Phoenix Online also traded on the NASDAQ, with the symbol UOPX. Whatever your opinion of the University of Phoenix, one must admit, they practiced all the right marketing techniques to build a highly successful and profitable educational institution. "Founded by a former professor of political science and economics at San Jose State University, Phoenix is the king of the for profits...." (Marcus, 2000. p. 44). How has the University of Phoenix been received by the academic and business community? "It was originally disparaged by accreditors and academics as a diploma mill, but is now a respected, accredited degree granting institution" (Strosnider, 1997, p. A32). Regardless of how one feels about the University of Phoenix, their marketing strategy is one for the texts books and to be emulated. They have the funds to develop and offer high end quality degree programs.

\section{MARKETING ISSUES IN EDUCATION}

Many education institutions, profits and non profits, depend on leads to increase enrollment. Enrollment representatives, then call these leads and attempt to sell the program. What are some marketing methods that can be used by universities to find leads for students? "A recently launched startup purports to be the first consumer to business Website. GoRefer.com, billed as a lead generation service, will start offering cash next month for every qualified lead that a registered user submits" (Gilbert, 2000, p. 20). How does this work? Anyone can refer a friend's name and phone number to GoRefer.com. The referee will typically get a $\$ 20$ stipend for each qualified lead. "Every referral provider will be like a virtual salesperson that gets a salary from us,' says CEO Gil Levi" (Gilbert, 2000, p. 20). Enrollment representatives can then call these potential students regarding their educational needs.

The exponential increase in the use of the Internet has allowed cyber marketing to get creative in its marketing methods. Applying some marketing savvy, "The University of Phoenix varies this theme to a much clearer and more positive statement. Running with a computer like banner, it shows some of users' favorite keys: enter, control, escape and shift. Each leads to a message about how a graduate degree from its online program will help the user get 'ctrl' and 'esc' their dreary Dilbert lives ..." (Carmichael, 1999, p. 38). This has marketing appeal. Most students aren't looking for an 'education', they are looking for a good job and view an education as a means to obtain this goal. A good marketer doesn't sell the features of the product they sell the benefits. Education marketers should sell the benefits of the degree or education, not just the features. They will accomplish more.

The educational landscape is changing, where now "students are increasingly being referred to as customers, and education is the product that is being offered" (Driscoll \& Wicks, 1998, p. 58). This has come about as a result of changes in “. . . demographics, declining government funding, and increasing competition ... [which has led] ... many universities to use aggressive marketing strategies" (Driscoll \& Wicks, 1998, p. 58). The bottom line is business schools need to act like a business to stay in business.

Another marketing issue in education is taking the approach that education is a service. The issues in providing any service, such as travel, hotel, health care, and banking, also apply to education. "The service provided by a university is intangible. It is provided by many people, (staff, librarians, faculty, etc.), and the time involved is extensive" (Driscoll \& Wicks, 1998, p. 58). Service quality is difficult to measure except by the presence or lack of customers. For education, one proxy for service quality might be the drop out rate, or the number of new students by referral. "The worldwide quality movement that has swept the manufacturing sector over the last decade is beginning to take shape in the service sector" (Bitner, Booms, \& Mohr, 1994, p. 95). This means if the student paying for their education or the Human Resources person signing the employee tuition reimbursement check does not feel they are 
getting enough value in return for their investment, they can go elsewhere. More than the state regulators, the regional accrediting bodies, and the Department of Education, the free market is what keeps the for-profits honest and on their toes. It may be that a for-profit education may soon be recognized as the best in quality. Recently, how well state regulators ensure quality in any state run program and the validity of the regional accrediting bodies is starting to be questioned.

Many have criticized the marketing of education that does little except maximize enrollment (Driscoll \& Wicks, 1998). This brings up the question, what is the purpose of marketing a university if not to increase enrollment? Doesn't that create more revenues for better facilities, better equipment, better curriculum, and better faculty pay? Many have criticized the concept of the free market, viewing students as consumers, determining the quality of the degree programs, or what is to be taught. However, this is the old school, tenure, talking. We have taught in economics courses for a long time now that the free market system would best resolve the question of what to produce and who should produce it. It is now time for the academics who have taught this, to practice what they preach.

It is not just the adult students that are so value conscious. "Today's high school students - part of the Baby Bust of the 1970s - are shopping around for higher education [and] ....to an unprecedented degree they are making their college selection choices based on image and value, as pragmatic consumers" (Spiegler, 1998, p. 50-51). Any educational institution marketer ignoring that market's concerns is not seeking to maximize their resources or stakeholder value. The state run colleges and universities as well as the private institutions must lean and apply sound marketing principles, growth strategies, service quality concepts and methods if they want to keep their doors open. It takes marketing research and innovative techniques to survive the enrollment numbers game now. "College kids may have weird hair and party more than people in the real world, but as consumers they are full fledged adults. Marketers who view college as a sort of way station before adulthood will need to adjust to the new reality" (Spiegler, 1998, p. 56). It is time to take a marketing approach and view students as consumers.

When a student goes through the registration process, the finance process, and sits in class, he/she is a customer. In most cases, the moment of truth is when the student interfaces with one of these service providers. "Thus, one central goal in the pursuit of 'zero defects' in service is to work toward $100 \%$ flawless performance in service encounters" (Bitner, Booms, \& Mohr, 1994, p. 95). What does this mean for educational faculty and administrative staff? They must be able and willing to treat students as customers. Granted, they are students, not customers, when it comes to grades, but the rest of the service encounter should meet the same service standards as any other service provider. Otherwise, the cost of not providing this means lost customers/students, negative word of mouth, poor employee morale, [or] redoing the service (Bitner, Booms, \& Mohr, 1994). An implication for education administrators and their staff is that "employees need appropriate coping and problem solving skills to handle customers..." (Bitner, Booms, \& Mohr, 1994, p. 109). Branch campus facilities can be placed based on demographics and acceptance criteria can be obtained from the enrollment application using well thought out strategic criteria. Since service marketing has risen to prominence, some have

proposed an expanded marketing mix for services consisting of the four traditional elements (product, price, place, promotion) and three new ones: physical evidence, (the physical surroundings and all tangible cures, participants (all human actors in the service encounter including firm personnel and other customers), and process (procedures, mechanisms, and flow of activities)" (Bitner, 1990, p. 70).

Educational institutions can excel in the marketing process by providing appropriate physical facilities even if it is a user friendly Web site for the online schools, let the students/consumers become participants in the education process and tailoring their degree to meet their needs, and developing better processes for application, registration, financial aid, and other student services. Those that are willing to do this are likely to be the ones still in existence a few years from now, or have the funding for better faculty pay, facilities, and research resources. Agree with it or not, the old concept that a student is not capable of intelligently informing the university of the kind of education they want is starting to crumble. The hammer of the free market and free choice will eventually have its way. 
For a traditional student, this means the quality of the classrooms, instruction, school reputation, administrative processes, campus facilities, and a demonstration of concern for students as customers. For an estudent, this could mean web design, quality instruction, quality text and curriculum, administrative services, technological support, electronic databases, and the perception they are not 'out of sight - out of mind'. This would be an excellent research project to study what particular components appeal to distance education/online students and how can they be appealed to once they are students as well as what features appeal to a traditional student. This must be designed into the curriculum as in any other product. It would appear appropriate to identify the market segment and type of person most likely to take a traditional degree program or an online degree program in order to conduct target marketing. It would seem an e-student would be more technically savvy, more affluent, and be more motivated since they are doing it on their own. However, more research in this area is required.

\section{THE IMPACT OF TECHNOLOGY AND BUSINESS PARTNERING ON MARKETING AN EDUCATION}

Technology, especially the Internet has changed the not only the way education is offered, but how it is marketed. For example, privately operated commercial Websites are using portals to market distance education programs. (Carr, 2000). Portals is a term for a number of Internet gateways which directs potential students to university home pages.

The Internet has been used in other ways. The College Board that oversees the SAT will soon start including student e-mail addresses on the mailing lists purchased by colleges and universities (Gose, 2000). Does e-mailing prospective students work? Christoph Guttentag, director of undergraduate admissions at Duke University says "Duke got good results when it used e-mail messages to promote the university to a small group of high school seniors last year" (Gose, 2000, p. A51). As the cost of a postage stamp goes up, the cost of an email address is looking more and more attractive.

\section{HOW ARE AGGRESSIVE MARKETING BY EDUCATIONAL INSTITUTIONS AND THE FOR-PROFITS VIEW BY TRADITIONAL ACADEMIA}

John Gamble complains in an entertaining fashion "about widespread faculty doubts concerning certain changes found in American Higher education" (Forsythe, 1999, p. 319). For some reason faculty seem to think they have something to fear. "The crux of his argument...is that universities are different from corporations in the private sector and cannot be managed like them. Universities produce knowledge, which cannot be delivered (and counted) like pepperoni pizzas" (Forsythe, 1999, p. 320). However, these are proving to be deadly arguments for today's education providers. Why can't education be delivered fast food style? Why can't the same curriculum and quality instruction be delivered closer to the student in classrooms in malls or hotels, and when they want it? The support services can be maintained at the main campus, but what says the actual instruction must happen on the campus? Why can't it happen where ever the student are? After all, isn't "place" one of the "P"s of marketing?

\section{WHAT DOES IT ALL MEAN}

Commenting more generally on the challenges facing business education, F. D. Choi (1993) has characterized the situation as follows:

Business school faculties will no longer be able to force feed irrelevant and outdated concepts to students...the users of our services... are ultimately the firms who hire our student. We must increasingly think of our students not as the end users of our services but as products trained to meet the needs of the market. If our products prove defective, we will not be able to 'sell' them... (p. 428-429).

Offering some blasphemous ideas among most educators, Herbert London stated "college costs have increased faster than inflation, while student teacher contact has diminished. The for-profit curriculum should do what almost all others today strenuously avoid: take the institutions for freedom seriously and study them in depth" (London, 1995, p. 191). Student today want degrees that are important to a potential employer. They want to be taught how to think and how to apply those thinking skills in a competitive society. Surviving educational institutions 
"would not dredge up obscure writers and revisionist history to maintain a fiction that all societies and all cultures are equally exalted. It would unapologetically affirm cultural excellence and give its students sustained exposure to it" (London, 1995, p. 191). Students want to be able to compete effectively in the global economy, communicate effectively, work as a team in a diverse society, interpret political events and thought, and apply these skills in an increasingly quality and cost conscious society. "Gender, guerrilla warfare and 'oppression' studies could be left to the not for-profit universities. A private university would pay top salaries but not provide tenure. For 'publish or perish,' it would substitute 'teach well or perish"' (London, 1995, p. 191). Like it or not, change is in the air. We either become a part of the solution or a part of the problem.

How does this affect us as a society with the need to compete globally? Dr. Gordon C. Winston, professor of economics at Williams College notes, "the traditional schools that can't give their (increasingly nontraditional) students the kind of education they want, when and where they want it, may wind upon the...beach, bypassed by new kinds of institutions that can" (Winston, 1999, p. 19). This needs to be a wake up call for many traditional educational organizations. "Because American public universities exist in a capitalistic culture, and because the days of ample public funding of higher education are over, there is no alternative to an increased emphasis on efficiency and rational use of scarce resources" (Forsythe, 1999, p. 319).

The day of for-profit higher educational institutions is not only here to stay, but it is the wave of the future. It is a matter of survival of the system. Academia must learn to practice the marketing principles it teaches as well as the operations and fiscal management to develop efficient processes and run lean organizations. If they are a state run legislated organization, they must still learn to apply sound quality management, productivity increases, process innovations, and marketing acumen to justify their tax dollar subsidies. "Despite belated protests to the contrary, public education seems to be in the midst of a step-by-step movement toward economist Milton Friedman's idea of salvation by competition" (Lewis, 2003, p. 563). Welcome to the real and a new world.

\section{REFERENCES}

1. Bitner, M. (1990). "Evaluating service encounters: the effects of physical surroundings and employee responses", Journal of Marketing, 54, 69-73.

2. Bitner, M., Booms, B. \& Mohr, L. (1994). "Critical service encounter, the employees point of view", Journal of Marketing, 58, 95-107.

3. Carmichael, M. (1999). "Cybercritique: University of Phoenix online cleverly uses 'CTRL", Advertising Age, 38 .

4. Carr, S. (2000). "Online learning's 'yellow pages' are bracing for a shakeout", The Chronicle of Higher Education, 46, A57-A58.

5. Choi, F. D. S. (1993). "Accounting Education for the 21str Century: Meeting the challenges". Issues in Accounting Education, 8, 423-430.

6. Cox, M. (1999). "Harvard seeks to leverage its brand name", Black Issues in Higher Education, 16, 53.

7. DiSilvio, P. (2003). "Harvard online: paradigm shift, or business as usual?" (Controversy), University Business, 6(6), 72.

8. Driscoll, C., \& Wicks, D. (1998). “The customer driven approach in business education: A possible danger?", Journal of Education for Business, 74, 58-61.

9. $\quad$ Forsythe, D. (1999). "Reactions to Learning Abut Lucy", Journal of Educational Thought, 33, 319-326.

10. Garber, M. (1996). "Wall Street PhD”, National Review, 48, 57-60.

11. Gilbert, A. (2000, September 4). "Referral site puts a price on shoppers' heads", Information Week, 20.

12. Gose, B. (2000). "Colleges plan to use e-mail as a new tool for recruiting", The Chronicle of Higher

Education, 46, A51-A52.

13. Greenberg, R., (2000). "Back to School", Techniques, 75, 14-17.

14. Heller, N. \& Associates. (2000). "U of Maryland creates for profit company to market DL programs", Heller Report on Educational Technology Markets, 11, 9.

15. Kirp, David L. (2003). "Education for Profit", Public Interest, 152, 100-113.

16. Leeds Report. (1999). “\$250 M private equity group founded to invest in education and training”, Lifelong Learning Market Report, 4, 4. 
17. Lewis, A. C. (2003). "Students as commodities", Phi Delta Kappan, 84(8), 563-565.

18. London, H. (1995, June 5). "Bait and switch in academe", Forbes, 155, 190-191.

19. Marcus, D. (2000, January 24). "A scholastic gold mine", U.S. News \& World Report, 128, 44.

20. Spiegler, M. (1998). "Have money will matriculate", American Demographics, 20, 50-56.

21. Strosnider, K. (1997). "An aggressive, for profit university challenges traditional colleges nationwide", The Chronicle of Higher Education, 43, A32.

22. Thomas, S. (1999). "Adult learning goes online", Computer Shopper, 19, 331.

23. Winston, G. (1999). "For-profit higher education: Godzilla or Chicken Little?”, Change, 31, 12-19.

\section{NOTES}

